\title{
ANALISIS PERSEPSI DAN PERILAKU MASYARAKAT TERHADAP KEPATUHAN KETENTUAN DAYA ANGKUT (STUDI PADA MOBIL BARANG BAK MUATAN TERBUKA )
}

\author{
Iswanto', Sutardjo², Moh Miftah ${ }^{3}$ \\ Politeknik Keselamatan Transportasi Jalan, Tegal, Indonesia ${ }^{123}$.
}

\begin{abstract}
Abstrak
Keselamatan transportasi merupakan suatu usaha penjaminan yang diberikan oleh para pemangku kepentingan kepada masyarakat sehingga masyarakat dapat memperoleh pelayanan terbaik melalui sektor transportasi tanpa harus berpikir berkali-kali untuk memilih solusi mobilitas yang tinggi baik untuk manusia ataupun barang. Isu sektor transportasi menunjukkan tren peningkatan yang sebanding kesemrawutan dalam pengelolaan transportasi baik dalam skala daerah maupun nasional. Sebagai contoh saja pertumbuhan angkutan umum berbasis teknologi yang secara kasat mata belum memiliki payung penyelenggaraan yang memadai, belum lagi dengan di galakkannya model ekonomi keuangan berbasis e-Commerce yang secara nyata berdampak pada meningkatnya mobilitas kendaraan di jalan raya. Penelitian pengaruh persepsi dan perilaku masyarakat ini dilaksanakan dengan menggunakan objek penelitian awak angkutan barang khusus bak muatan terbuka. Dengan menggunakan alat analisis regresi maka diperoleh kesimpulan bahwa persepsi dan perilaku masyarakat memiliki pengaruh $80,1 \%$ terhadap kepatuhan daya angkut muatan bak terbuka
\end{abstract}

\section{Kata Kunci : Daya Angkut, Muatan kendaraan}

\section{PENDAHULUAN}

\section{Latar Belakang}

Keselamatan transportasi maupun pemakai jasa transportasi yang merupakan suatu usaha penjaminan yang diberikan oleh para pemangku kepentingan kepada masyarakat sehingga masyarakat dapat memperoleh pelayanan terbaik melalui sektor transportasi tanpa harus berpikir berkali-kali untuk memilih solusi mobilitas yang tinggi baik untuk manusia ataupun barang. Usaha peningkatan pelayanan dibidang keselamatan transportasi ini merupakan kepentingan bersama dari semua pihak baik regulator baik tingkat pusat maupun daerah, operator harus terkoordinasi dengan baik, selaras dan berkelanjutan. 
Melalui Rencana Umum Nasional Keselamatan Transportasi yang ditindaklanjuti dengan program Dekade Aksi keselamatan Transportasi Jalan 2011 -2020 pemerintah berusaha secara konkrit dalam isu keselamatan transportasi jalan yang dituangkan ke dalam 5 pilar Rencana Umum Nasional Keselamatan transportasi Jalan.

\section{Rumusan Masalah}

1. Apakah persepsi masyarakat memiliki pengaruh terhadap kepatuhan ketentuan daya angkut kendaraan bermotor?

2. Apakah perilaku masyarakat memiliki pengaruh terhadap kepatuhan ketentuan daya angkut kendaraan bermotor?

\section{Tujuan Penelitian}

Tujuan Penelitian Tujuan dari penelitian ini adalah :

1. Mengetahui persepsi masyarakat terhadap ketentuan daya angkut kendaraan bermotor.

2. Mengetahui perilaku masyarakat terhadap ketentuan daya angkut kendaraan bermotor

\section{LANDASAN TEORI}

Persepsi merupakan suatu proses yang didahului oleh penginderaan. Penginderaan adalah merupakan suatu proses di terimanya stimulus oleh individu melalui alat penerima yaitu alat indera. Pada umumnya stimulus tersebut diteruskan oleh saraf ke otak melalui pusat susunan saraf dan proses selanjutnya merupakan proses persepsi. Stimulus diterima oleh alat indera, kemudian melalui proses persepsi sesuatu yang di indera tersebut menjadi sesuatu yang berarti setelah diorganisasikan dan diinterpretasikan (Davidoff dalam Walgito, 2000:53).

Dengan demikian persepsi masyarakat dapat disimpulkan adalah tanggapan atau pengetahuan lingkungan dari kumpulan individu-individu yang saling berinteraksi karena mempunyai nilai-nilai, norma-norma, cara-cara dan prosedur merupakan kebutuhan bersama berupa suatu sistem adat-istiadat yang bersifat kontinue dan terikat oleh suatu identitas bersama yang diperoleh melalui interpretasi data indera. 
Robbins ( 2001 : 89 ) mengemukakan bahwasannya ada 3 faktor yang dapat mempengaruhi persepsi masyarakat, yaitu:

a. Pelaku persepsi, bila seseorang memandang suatu objek dan mencoba menafsirkan apa yang dilihatnya dan penafsiran itu sangat dipengaruhi oleh karakteristik pribadi dari pelaku persepsi individu itu.

b. Target atau objek, karakteristik- karakteristik dan target yang diamati dapat mempengaruhi apa yang dipersepsikan. Target tidak dipandang dalam keadaan terisolasi, hubungan suatu target dengan latar belakangnya mempengaruhi persepsi seperti kecendrungan kita untuk mengelompokkan benda-benda yang berdekatan atau yang mirip.

c. Situasi, dalam hal ini penting untuk melihat konteks objek atau peristiwa sebab unsur-unsur lingkungan sekitar mempengaruhi persepsi kita.

Perilaku merupakan hasil daripada pola dan cara berpikir individu yang biasanya berwujud pengetahuan, tindakan dan sikap atau dapat dikatakan bahwa perilaku merupakan tindakan atau sikap yang terbentuk sebagai respon atas peristiwa yang sedang terjadi di lingkungan sekitar individu. Maka dapat dikatakan bahwa perilaku individu akan mengalami perubahan seiring perubahan lingkungan yang terjadi dimasyarakat.

Perilaku adalah suatu kegiatan atau aktifitas organisme (makhluk hidup) yang bersangkutan. Jadi yang dimaksud perilaku manusia pada hakikatnya adalah tindakan atau aktifitas dari manusia itu sendiri yang mempunyai bentangan sangat luas antara lain, berjalan, berbicara, menangis, tertawa, bekerja, kuliah, menulis, membaca dan sebagainya (Notoatmodjo, 2007).

Sedangkan menurut Sunaryo (2006), perilaku adalah aktivitas yang timbul karena adanya stimulus dan respon serta dapat diamati secara langsung maupun tidak langsung. Semua kegiatan atau aktifitas manusia, baik dapat diamati langsung maupun tidak langsung yang diamati oleh pihak luar. (Notoatmodjo, 2007) perilaku adalah keyakinan mengenai tersedianya atau tidaknya kesempatan dan sumber yang diperlukan.

Perilaku manusia tidak timbul dengan sendirinya, tetapi akibat adanya rangsangan (stimulus), baik dalam dirinya(internal) maupun dari luar individu(eksternal) (Sunaryo, 2006). Proses pembentukan perilaku dipengaruhi olehbeberapa faktor yang berasal dari dalam dirindividu itu sendiri, faktor-faktor tersebutantara lain : 
1) Persepsi adalah sebagai pengalaman yang dihasilkan melalui indera penglihatan, pendengaran, penciuman, dan sebagainya.

2) Motivasi. Motivasi diartikan sebagai dorongan untuk bertindak untuk mencapai sutau tujuan tertentu, hasil dari pada dorongan dan gerakan ini diwujudkan dalam bentuk perilaku

3) Emosi. Perilaku juga dapat timbul karena emosi, Aspek psikologis yang mempengaruhi emosi berhubungan erat dengan keadaan jasmani, sedangkan keadaan jasmani merupakan hasil keturunan (bawaan), Manusia dalam mencapai kedewasaan semua aspek yang berhubungan dengan keturunan dan emosi akan berkembang sesuai dengan hukum perkembangan, oleh karena itu perilaku yang timbul karena emosi merupakan perilaku bawaan.

4) Belajar. Belajar diartikan sebagai suatu pembentukan perilaku dihasilkan dari praktekpraktek dalam lingkungan kehidupan. Sehingga dapat dikatakan bahwa belajar adalah proses perubahan perilaku yang berdasarkan kepada perilaku perilaku sebelumnya.

5) memahami dan mengerti akan suatu kondisi lingkungan.

\section{METODOLOGI PENELITIAN}

Pengumpulan data merupakan salah satu bagian yang penting dalam pelaksanaan penelitian. Pengumpulan data yang baik sebaiknya tidak hanya sebatas kuantitas dari populasi dan sampel tetapi juga sebaiknya memperhatikan teknik teknik pengumpulan data yang baik sehingga tidak terjadi bias dan data yang tidak valid sehingga berdampak pada hasil penelitian.

1) Teknik pengumpulan data

Dalam penelitian ini, data primer yang dibutuhkan oleh peneliti akan diperoleh melalui:

a. Pengamatan langsung

Observasi atau pengamatan secara langsung dilakukan dilokasi penelitian guna mendapatkan data yang nyata sesuai dengan kondisi pada saat dilaksanakan penelitian.

Kuisioner Peneliti akan memberikan daftar pertanyaan kepada responden yang terdiri dari penjabaran dari indikator indikator dari operasional variabel yang telah ditentukan.

b. Wawancara 
Wawancara dilakukan kepada sejumlah narasumber yang memiliki kompetensi dibidangnya sehingga diperoleh jawaban yang reliabel dan valid.

Sedangkan untuk pengumpulan data sekunder yang akan dipergunakan dalam penelitian ini dilakukan melalui studi iterasi dan kajian pustaka atas berbagai dokumen sumber yang telah diterbitkan oleh pihak lain selain peneliti yang kemudian dilakukan pemilahan berdasarkan tingkat reliabilitasnya.

2) Sampel

Teknik pengambilan sampel merupakan bagian yang perlu diperhatikan dalam sebuah penelitian, hal tersebut disebabkan karena jumlah sampel yang diambil oleh peneliti harus benar benar dapat mewakili jumlah populasi yang ada. Dengan jumlah sampel yang mencukupi maka akan memberikan kebaikan terhadap hasil penelitian yang dilakukan.

Dalam penelitian ini peneliti akan menggunakan metode pengambilan sampel dengan teknik Purposive sampling, alasan digunakannya teknik tersebut adalah peneliti telah menentukan kriteria kriteria khusus terhadap sampel yang akan di teliti yakni kendaraan bermotor angkutan barang dengan bak muatan terbuka.

3) Skala

Skala merupakan alat pengukuran yang dipergunakan untuk mengubah data/informasi yang merupakan jawaban atas kuisioner yang telah dirumuskan menjadi sebuah data kuantitatif. Dalam penelitian ini skala yang dipergunakan adalah skala ordinal.

\section{HASIL PENELITIAN}

\section{1) Uji Instrumen Penelitian}

Dalam pengujian instrument penelitian, peneliti menggunakan Uji Validitas untuk menguji tingkat kevalidan/keshohehan butir pertanyaan dan Uji Reliabilitas untuk mengetahui tingkat kehandalan butir pertanyaan pada kuesioner.

Pengujian instrument menggunakan uji validitas dilakukan menggunakan software statistic SPSS versi 17.0 Untuk mendapatakan nilai kevalidan yang di maksud maka harus memenuhi 
kriteria $r$ nitung lebih besar dari $r$ tabel dimana nilai $r$ tabel ditentukan sebesar 0,278 dengan taraf signifikansi 5\% dan derajat bebas ( $d f$ ) 48 (jumlah sampel-2). Berikut hasil uji validitas untuk tiap skor variabel Persepsi dan Perilaku.

Uji Validitas

Tabel 1. Hasil Uji Validitas Butir Pertanyaan Kuesioner

\begin{tabular}{|c|c|c|c|c|}
\hline Variabel & $\begin{array}{l}\text { Item } \\
\text { pertanyaan }\end{array}$ & mations & nasoel & Keterangan \\
\hline \multirow{39}{*}{$\begin{array}{l}\text { Persepsi } \\
\text { dan } \\
\text { perilaku }\end{array}$} & 1 & 0.318 & 0.278 & Valid \\
\hline & 2 & 0.369 & 0.278 & Valid \\
\hline & 3 & 0.406 & 0.278 & $\begin{array}{l}\text { Valid } \\
\end{array}$ \\
\hline & 4 & 0.290 & 0.278 & $\begin{array}{l}\text { Valid } \\
\text { Val }\end{array}$ \\
\hline & 5 & 0.446 & 0.278 & Valid \\
\hline & 6 & 0.416 & 0.278 & Valid \\
\hline & $\overline{7}$ & 0.308 & 0.278 & Valid \\
\hline & 8 & 0.457 & 0.278 & $\begin{array}{l}\text { Valid } \\
\text { Val }\end{array}$ \\
\hline & 9 & 0.330 & 0.278 & $\begin{array}{l}\text { Valid } \\
\text { Val }\end{array}$ \\
\hline & 10 & 0.30 & 0.278 & Valid \\
\hline & 11 & 0.313 & 0.278 & Valid \\
\hline & 12 & 0.335 & 0.278 & Valid \\
\hline & 13 & 0.289 & 0.278 & $\begin{array}{l}\text { Valid } \\
\end{array}$ \\
\hline & 14 & 0.40 & 0.278 & Valid \\
\hline & 15 & 0.455 & 0.278 & $\begin{array}{l}\text { Valid } \\
\end{array}$ \\
\hline & 16 & 0.387 & 0.278 & $\begin{array}{l}\text { Valid } \\
\end{array}$ \\
\hline & 17 & 0.363 & 0.278 & $\begin{array}{l}\text { Valid } \\
\text { Val }\end{array}$ \\
\hline & 18 & 0.370 & 0.278 & $\begin{array}{l}\text { Valid } \\
\text { Val }\end{array}$ \\
\hline & 19 & 0.445 & 0.278 & Valid \\
\hline & 20 & 0.368 & 0.278 & Valid \\
\hline & 21 & 0.340 & 0.278 & $\begin{array}{l}\text { Valid } \\
\text { Val }\end{array}$ \\
\hline & 22 & 0.407 & 0.278 & Valid \\
\hline & 23 & 0.371 & 0.278 & $\begin{array}{l}\text { Valid } \\
\end{array}$ \\
\hline & 24 & 0.444 & 0.278 & $\begin{array}{l}\text { Valid } \\
\text { Val }\end{array}$ \\
\hline & 25 & 0.329 & 0.278 & $\begin{array}{l}\text { Valid } \\
\text { Val }\end{array}$ \\
\hline & 26 & 0.356 & 0.278 & $\begin{array}{l}\text { Valid } \\
\text { Val }\end{array}$ \\
\hline & 27 & 0.284 & 0.278 & Valid \\
\hline & 28 & 0.337 & 0.278 & $\begin{array}{l}\text { Valid } \\
\end{array}$ \\
\hline & 29 & 0.295 & 0.278 & $\begin{array}{l}\text { Valid } \\
\text { Val }\end{array}$ \\
\hline & 30 & 0.388 & 0.278 & Valid \\
\hline & 31 & 0.395 & 0.278 & $\begin{array}{l}\text { Valid } \\
\end{array}$ \\
\hline & 32 & 0.330 & 0.278 & $\begin{array}{l}\text { Valid } \\
\text { Val }\end{array}$ \\
\hline & 33 & 0.396 & 0.278 & Valid \\
\hline & 34 & 0.327 & 0.278 & $\begin{array}{l}\text { Valid } \\
\text { Val }\end{array}$ \\
\hline & 35 & 0.306 & 0.278 & $\begin{array}{l}\text { Valid } \\
\end{array}$ \\
\hline & 36 & 0.350 & 0.278 & Valid \\
\hline & 37 & 0.399 & 0.278 & Valid \\
\hline & 38 & 0.297 & 0.278 & $\begin{array}{l}\text { Valid } \\
\end{array}$ \\
\hline & 39 & 0.318 & 0.278 & Valid \\
\hline
\end{tabular}

(Sumber : Data yang diolah)

Uji Reliabilitas 
Berdasarkan kriteria yang tersebut diatas maka dapat di ketahui bahwa tingkat reliabilitas kuesioner penelitian ini adalah tinggi atau dapat dikatakan kuesioner tersebut mempunyai reliabel dan kehandalan yang tinggi dengan nilai 0.716 .

hal tersebut dapat diketahui dari tabel dan perhitungan sebagai berikut :

Tabel 2. Realibility Statics

\begin{tabular}{|l|l|}
\hline $\begin{array}{l}\text { Cronbach's } \\
\text { Alpha }\end{array}$ & N of ltems \\
\hline 716 & 40 \\
\hline
\end{tabular}

(Sumber : Data yang diolah)

\section{2) Analisis Data}

Analisis regresi linear digunakan untuk mengetahui ada tidaknya pengaruh dari variabel persepsi dan perilaku terhadap kepatuhan ketentuan daya angkut. Berikut ini hasil perhitungan regresi linear menggunakan program statistik SPSS 17.0.

Berdasarkan hasil perhitungan analisis regresi yang diolah dengan menggunakan alat bantu program statistik SPSS versi 17.0 diatas maka dapat kita tentukan persamaan regresinya yaitu :

Tabel 3. Coefficients

\begin{tabular}{|c|c|c|c|c|c|c|c|}
\hline \multirow[t]{2}{*}{ Model } & \multicolumn{2}{|c|}{$\begin{array}{l}\text { Unstandardized } \\
\text { Coefficients }\end{array}$} & \multirow{2}{*}{ 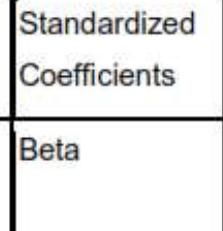 } & \multirow[b]{2}{*}{$T$} & \multirow[b]{2}{*}{ Sig. } & \multicolumn{2}{|c|}{$\begin{array}{l}\text { Collinearity } \\
\text { Statistics }\end{array}$} \\
\hline & B & $\begin{array}{l}\text { Std. } \\
\text { Error }\end{array}$ & & & & $\begin{array}{l}\text { Toleran } \\
\text { ce }\end{array}$ & VIF \\
\hline $\begin{array}{l}1 \text { (Consta } \\
\text { nt) }\end{array}$ & 19.453 & 4.153 & & 4.684 & .000 & & \\
\hline $\begin{array}{l}\text { Kepatu } \\
\text { han_da } \\
\text { ya } \\
\text { angkut }\end{array}$ & .242 & .017 & .895 & $\begin{array}{r}13.90 \\
1\end{array}$ & .000 & 1.000 & 1.000 \\
\hline
\end{tabular}

a. Dependent Variable: Kepatuhan

(Sumber : Data yang diolah)

Persamaan regresi diatas dapat diinterpretasikan sebagai berikut :

$$
Y=19,453+0,242 x
$$


Keterangan :

$\mathrm{Y}=$ Kepatuhan ketentuan daya angkut

$\mathrm{X}=$ Persepsi dan perilaku

Variabel Persepsi dan Perilaku $(X)$ mempunyai koefisien regresi sebesar 0,242 dan bernilai positif, hal ini berarti bahwa Persepsi dan Perilaku mempunyai pengaruh positif terhadap Kepatuhan ketentuan daya angkut $(Y)$, dengan demikian apabila Persepsi dan Perilaku meningkat maka akan terjadi peningkatan pada kepatuhan ketentuan daya angkut dan apabila terjadi penurunan Persepsi dan Perilaku maka dapat menimbulkan penurunan kepada kepatuhan ketentuan daya angkut.

Uji korelasi Rank Spearman digunakan untuk Digunakan untuk menguji hipotesis hubungan antara dua variabel dan untuk melihat kuat lemahnya hubungan dan arah hubungan antara dua variabel. Berikut hasil perhitungan uji korelasi Rank Spearman menggunakan program statistik SPSS versi 17.0.

Tabel 4. Correlations

\begin{tabular}{|c|c|c|c|c|}
\hline & & & $\begin{array}{l}\text { Persepsi dan } \\
\text { perilaku }\end{array}$ & $\begin{array}{l}\text { Kepat } \\
\text { uhan }\end{array}$ \\
\hline \multirow[t]{2}{*}{ Spearman's rho } & $\begin{array}{l}\text { Pers } \\
\text { psi__ } \\
\text { peril } \\
\text { aku }\end{array}$ & $\begin{array}{l}\text { Correlation } \\
\text { Coefficient } \\
\text { Sig. (2-tailed) } \\
\text { N }\end{array}$ & $\begin{array}{r}1.000 \\
. \\
50\end{array}$ & $\begin{array}{r}.858 \\
.000 \\
50\end{array}$ \\
\hline & $\begin{array}{l}\text { Kep } \\
\text { atuh } \\
\text { an }\end{array}$ & $\begin{array}{l}\text { Correlation } \\
\text { Coefficient } \\
\text { Sig. (2-tailed) } \\
\text { N }\end{array}$ & $\begin{array}{r}.858 * \\
.000 \\
50\end{array}$ & 50 \\
\hline
\end{tabular}

**. Correlation is significant at the 0.01 level (2-tailed).

(Sumber : Data yang diolah)

Berdasarkan tabel diatas diperoleh nilai korelasi sebesar 0,858 $(r=0,858)$ bernilai positif dan mendekati angka 1, sehingga berdasarkan indeks korelasi hal ini dapat diartikan bahwa Persepsi dan Perilaku mempunyai hubungan yang kuat dan positif terhadap Kepatuhan ketentuan daya angkut Uji Signifikansi Koefisien Regresi. 
Setelah melakukan analisis regresi maka dilakukan uji koefisien regresi dengan tujuan untuk menguji tingkat signifikansi dari pengaruh variable $X$ (Persepsi dan Perilaku) terhadap variable Y (kepatuhan).

Pengambilan keputusan didasarkan pada hipotesis yang diajukan yaitu :

$H_{0}: B=0$, berarti variabel $X$ tidak memiliki pengaruh yang signifikan terhadap variabel $Y$.

$H_{1}: ß \neq 0$, berarti variabel $X$ memiliki pengaruh yang signifikan terhadap variabel $Y$.

Dengan kriteria sebagai berikut :

$\mathrm{H}_{0}$ diterima apabila $\mathrm{t}$ hitung $<\mathrm{t}$ tabel

Ho ditolak apabila $t$ hitung $>t$ tabel

Maka Berdasarkan nilai t hitung dan signifikansi yang diperoleh dari perhitungan analisis regresi yaitu sebesar 13,901 dan sig. 0,000, dan apabila dibandingkan dengan nilai $t$ tabel dengan derajat kebebasan 48 (responden - 2) yang mempunyai nilai sebesar 2,010 dengan signifikansi 0,050 maka dapat diambil keputusan untuk menerima $\mathrm{H}_{1}$ dan menolak $\mathrm{H}_{0}$ karena nilai $t$ hitung $>t$ tabel.

\section{Gambar 1. Kurva Penolakan Ho}

\section{Kurva Penolakan $\mathrm{H}_{0}$}

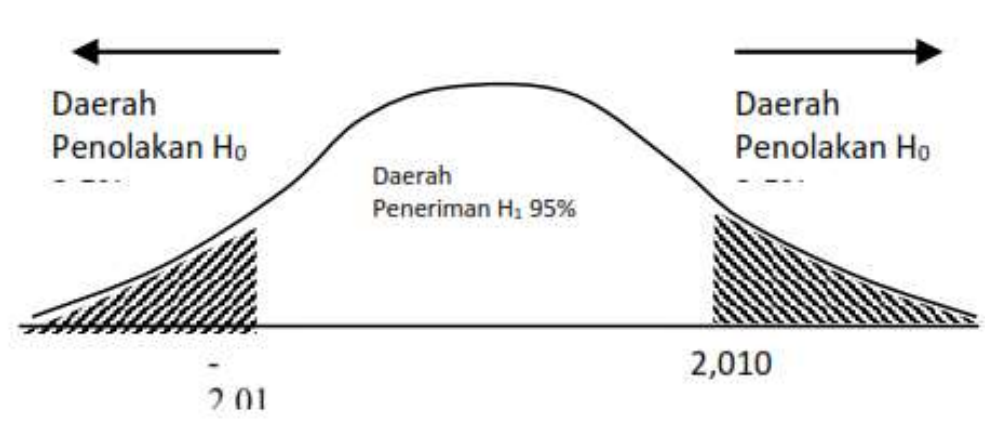

Dengan demikian berdasarkan pengujian hipotesis dengan menggunakan kurva daerah penolakan $\mathrm{H}_{0}$ diatas, maka dapat diambil keputusan bahwa Persepsi dan Perilaku mempunyai pengaruh signifikan terhadap kepatuhan ketentuan daya angkut dengan tingkat signifikansi 95\%. 
Uji Koefisien Determinasi

Tabel 5. Model Summary

Tabel 8. Model Summaryb

\begin{tabular}{|l|l|r|l|r|r|}
\hline $\begin{array}{l}\text { Mod } \\
\text { el }\end{array}$ & $R$ & $R$ Square & $\begin{array}{l}\text { Adjusted R } \\
\text { Square }\end{array}$ & $\begin{array}{l}\text { Std. Error of } \\
\text { the Estimate }\end{array}$ & Durbin-Watson \\
\hline 1 & $895^{2}$ & .801 & .797 & .77721 & 2.046 \\
\hline
\end{tabular}

a. Predictors: (Constant),Persepsi dan perilaku

b. Dependent Variable: Kepatuhan

(Sumber : Data yang diolah)

Dari tabel diatas diperoleh nilai $\mathrm{R}$ square sebesar 0,801 atau $80,1 \%$ sehingga dapat dijelaskan bahwa variabel Persepsi dan Perilaku memiliki kontribusi sebesar $80,1 \%$ terhadap Kepatuhan ketentuan daya angkut dan 19,9\% lainnya dipengaruhi oleh faktor-faktor diluar variabel yang di teliti.

\section{KESIMPULAN}

Berdasarkan hasil analisis yang dibahas sebelumnya maka dapat disimpulkan bahwa :

1) Dengan menggunakan analisis regresi diperoleh persamaan $Y=19,453+0,242 x$ yang berarti Persepsi dan Perilaku mempunyai pengaruh yang searah terhadap Kepatuhan ketentuan daya angkut,dan setelah dilakukan uji signifikansi dengan taraf signifikansi 0,05 dengan nilai $t$ hitung besar dari nilai t tabel 13,901 dimana lebih maka diartikan bahwa Persepsi dan Perilaku mempunyai pengaruh yang signifikan terhadap Kepatuhan ketentuan daya angkut. 
2) Dengan menggunakan analisis korelasi Rank Spearman diperoleh nilai $r$ sebesar 0,858 dan bertanda positif, sehingga apabila dimasukkan dalam interval skor korelasi maka nilai tersebut termasuk kategori kuat positif. Dan setelah dilakukan uji determinasi dengan perolehan nilai sebesar $80,1 \%$ maka dapat diartikan bahwa Persepsi dan Perilaku memiliki kontribusi sebesar $80,1 \%$ dan sisa sebesar $19,9 \%$ merupakan kontribusi dari variabel yang tidak diteliti dalam penelitian ini.

3) Dari kesimpulan diatas maka dapat kiranya diberikan saran kepada seluruh pemangku kepentingan diantaranya, Kementerian perhubungan sebagai regulator, perusahaan angkutan sebagai operator dan masyarakat sebagai bagian yang tak terpisahkan saling mendukung dalam berbagai upaya peningkatan kesadaran keselamatan transportasi jalan pada umumnya dan tentang kesadaran daya angkut pada khususnya.

\section{DAFTAR PUSTAKA}

Ghozali, Imam. 2005. Aplikasi Analisis Multivariate dengan Program SPSS. Semarang: Universitas Diponegoro.

Hardjana, A. M. 2001. Training Sumber Daya Manusia yang Efektif. Yogyakarta. Kanisiun.

Syahrifadilla, Novi. 2007. Peranan Pendidikan dan Pelatihan terhadap Kualitas Pegawai pada PT. Bank Sumut Kantor Pusat Medan. Online.

Republik Indonesia.2003. Undang-Undang No. 13 Tahun 2003 tentang Ketenagakerjaan. Lembaran Negara RI Tahun 2003, No. 39. Jakarta. Sekretariat Negara. 